\title{
Evaluation of Brain Death in Children: A Single Center Experience
}

\author{
Mahmut Aslan $^{1 *}$ (D), Serkan Kırık ${ }^{1}$ (D), Bilge Özgör ${ }^{1}$ (D), Neslihan Aslan ${ }^{2}$ (D), Serdal Güngör ${ }^{1}$ \\ ${ }^{1}$ Department of Pediatric Neurology, Faculty of Medicine, Inonu University, Malatya, Turkey \\ ${ }^{2}$ Malatya Training and Research Hospital, Department of Pediatrics, Malatya, Turkey \\ * Corresponding author: Mahmut Aslan E-mail: dr_mahmut_21@hotmail.com ORCID: 0000-0002-5355-8994 \\ Received: 19 May 2019 Accepted: 30 May 2019
}

\begin{abstract}
Introduction: Brain death is defined as a status of apnea, coma and the absence of brainstem reflexes, in addition to the presence of electrocerebral silence (ECS) on an electroencephalography (EEG). Trauma and anoxic encephalopathy are the most common causes of brain death in children, with incidences of brain death reported to vary between 0.65-1.2 percent. A diagnosis of brain death can be made based on a detailed anamnesis, physical examination findings and supportive test results. When pediatric patients are being evaluated by EEG, they should also be assessed in terms of medications, metabolic encephalopathy, hypothermia, electrolyte imbalance and acid-base imbalance.
\end{abstract}

Patients and Methods: The present study included patients who suffered brain death during hospitalization in the pediatric intensive care unit of Inonu University Turgut Ozal Medical Center between 2010 and 2017. The medical files of the patients were reviewed retrospectively. All patients included in the study underwent an EEG and an apnea test was performed on all patients. The cerebral blood flow (CBF) measurement was obtained through a Computerized Tomography Angiography (CTA), and all patients underwent a Magnetic Resonance Angiography (MRA) and a Transcranial Doppler Ultrasonography (TCD).

Results: Of the 20 patients included in the study, nine (45\%) were female and 11 (55\%) were male, with a mean age of $8.47 \pm 5.73$ years. Of the total, seven patients presented with fulminant hepatitis, three with trauma, three with sepsis, two with drowning, two with cerebrovaskuler disease (CVD), and one patient each with lymphoma, suicide and electric shock. The families of only two (10\%) patients donated the organs of the deceased. Of the 20 patients, four were Syrian, and of which were being monitored with the diagnosis of liver failure. An apnea test was positive in all patients, and in all patients, the EEG findings supported brain death. Imaging methods were carried out to demonstrate the absence of CBF flow in 11 (55\%) patients, and diabetes insipidus (DI) developed in nine (45\%) of the patients with brain death.

Conclusion: In conclusion, a multidisciplinary approach is required for the diagnosis of brain death. An evaluation of laboratory findings and EEG results together with the findings of a physical examination is important, particularly in centers like our clinics where more than 50 pediatric transplantations are carried out each year. The development of hypernatremia in patients with DI is now an important parameter in the loss of brain function.

Keywords: Brain death, Childhood, EEG

( 2019 by the authors; licensee MEDITAGEM Ltd., Turkey. This article is an open access article distributed under the terms and conditions of the Creative Commons Attribution License (http://creativecommons.org/licenses/by/4.0/). 


\section{ÖZ}

Giriş ve Amaç: Beyin ölümü apne, koma ve beyin sapı reflekslerinin bulunmamasına ek olarak elektroserebral sessiz elektroensefalografi (EEG) bulunması durumudur. Çocuklarda beyin ölümü en sık travma ve anoksik ensefalopati sonucu ortaya çıkar. Beyin ölümü insidansının \%0,65 ila \%1,2 arasında değiştiğini bildirmiştir. Beyin ölümü tanısı iyi bir anamnez, fizik muayene ve yardımcı testler ile konulur. Pediatrik hastalar EEG açısından değerlendirilirken mutlaka medikasyon, metabolik ensefalopati, hipotermi, elektrolit dengesizliği, asit-baz dengesizliği açısında değerlendirilmelidir.

Hastalar ve Metod: Çalışmamıza 2010-2017 yılları arasında İnönü Üniversitesi Turgut Özal Tıp Merkezi çocuk yoğun bakım ünitesinde beyin ölümü gerçekleşen hastalar alınmıştır. Hastaların dosyaları retrospektif olarak tarandı. Çalışmamıza alınan hastaların tamamına EEG çekildi. Hastalarımızın tamamına apne testi yapıldı. Beyin kan akımı (CSF) akımı ölçümünde bilgisayarlı tomografi anjiyografi (BTA), manyetik rezonans anjiyografi (MRA), transkraniyal doppler ultranografi (TCD) yapıldı.

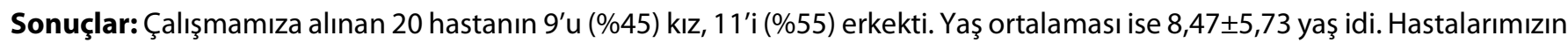
7'si fulminan hepatit, 3'ü travma, 3'ü sepsis, 2'si suda boğulma, 2'si SVO tanısı, birer hasta ise lenfoma, suicide, elektrik çarpması ile takip edilmişti. Yirmi hastamızın sadece 2'si (\%10) için aile organ bağışında bulunmuştu. Yirmi hastamızın 4'ü Suriyeli idi ve 4 hastanın tamımı da karaciğer yetmezliği ile takip edilmekteydi. Tüm hastaların apne testi pozitifti, hastalarımızın tamamında EEG bulguları beyin ölümünü destekleyici nitelikteydi. Hastalarımızın 11'ine (\%55) CSF akımının yokluğunu gösterebilmek adına görüntüleme yöntemleri yapıldı. Beyin ölümü gerçekleşen hastalarımızın 9'unda (\%45) DI gelişti.

Sonuç: Sonuç olarak beyin ölümü tanısı multidisipliner yaklaşım gerektirir. Fizik muayenenin yanında laboratuvar bulgularının EEG'nin birlikte değerlendirilmesi özellikle klinğimiz gibi 50'den fazla pediatrik transplantın yapıldığı merkezler açısından önemlidir. Hastalarda hipernatremi ve DI gelişimi beyin fonksiyonlarında kaybın bir göstergesidir.

Anahtar kelimeler: Beyin ölümü, Çocukluk çağı, EEG

\section{INTRODUCTION}

A diagnosis of brain death in infants and children is made after a careful review of the medical history and a detailed neurological examination that demonstrates an irreversible loss of brain function [1]. Trauma and anoxic encephalopathy are the most common causes of brain death in children [2]. In the United States and in many other countries, the pediatric brain death guidelines issued in 1987 by the American Academy of Pediatricians (AAP) has served as the main guideline for the identification of brain death in children, and this guideline was revised in 2011 [1, 2]. In addition to the presence of apnea and coma and the absence of brainstem reflexes, electrocerebral silence (ECS) on an electroencephalography (EEG) most probably reflects brain death in a patient on long-term mechanical ventilation [2]. The guidelines underline the need for medical screening and an EEG review before declaring brain death [1,2].

In the United States, brain death is declared in almost 1,800 children every year [1]. In studies performed in pediatric intensive care units in the 1990s, the incidence of brain death in infants and children was reported to vary between 0.65 and 1.2 percent [2]. Almost all guidelines have highlighted that the triad of coma, absence of brainstem reflexes and unsuccessful apnea test are essential for a diagnosis of brain death. However, most physicians should perform EEG or brain imaging to support brain death. Clinical evaluations and all the relevant diagnostic investigations are important for a definite clinical decision [3] (Table 1). Moreover, in the most recent guidelines, issued in 2011, it is reported that EEG and CSF evaluations alone are not sufficient for a diagnosis of brain death and cannot replace neurological examinations [1-3].

The majority of physicians still rely on an isoelectric EEG (ECS) combined with the triad of coma, the absence of brainstem reflexes and an unsuccessful apnea test, as a common approach to the diagnosis of brain death [3]. While pediatric patients are evaluated by EEG, they should also be assessed in terms of medications, metabolic encephalopathy, hypothermia, electrolyte imbalance and acid-base imbalance [4]. In a study that contributed significantly to the guidelines, ECS was detected again in the follow-up EEG of 97 percent of the children whose initial EEG showed ECS. In 1994, ECS was defined as "there should be an isoelectric line in recordings for at least 30 minutes and no electrical activity above $2 \mu \mathrm{V}$ at $2 \mu \mathrm{V} / \mathrm{mm}$ sensitivity (at filter settings of 0.1 or 0.3 seconds at $70 \mathrm{~Hz}$ )" [3-4]. 
Table 1. Neurologic Examination Components to Assess for Brain Death in Neonates, Infants and Children* Including Apnea Testing

Reversible conditions or conditions that can interfere with the neurologic examination must be excluded prior to brain death testing.

See text for discussion

1. Coma. The patient must exhibit complete loss of consciousness, vocalization and volitional activity.

- Patients must lack all evidence of responsiveness. Eye opening or eye movement to noxious stimuli is absent.

- Noxious stimuli should not produce a motor response other than spinally mediated reflexes. The clinical differentiation of spinal responses from retained motor responses associated with brain activity requires expertise.

2. Loss of all brain stem reflexes including:

Midposition or fully dilated pupils which do not respond to light.

Absence of pupillary response to a bright light is documented in both eyes. Usually the pupils are fixed in a midsize or dilated position (4-9 $\mathrm{mm}$ ). When uncertainty exists, a magnifying glass should be used.

Absence of movement of bulbar musculature including facial and oropharyngeal muscles.

Deep pressure on the condyles at the level of the temporomandibular joints and deep pressure at the supraorbital ridge should produce no grimacing or facial

muscle movement.

Absent gag, cough, sucking, and rooting reflex

The pharyngeal or gag reflex is tested after stimulation of the posterior pharynx with a tongue blade or suction device. The tracheal reflex is most reliably tested

by examining the cough response to tracheal suctioning. The catheter should be inserted into the trachea and advanced to the level of the carina followed by 1

or 2 suctioning passes.

\section{Absent corneal reflexes}

Absent corneal reflex is demonstrated by touching the cornea with a piece of tissue paper, a cotton swab, or squirts of water. No eyelid movement should be

seen. Care should be taken not to damage the cornea during testing.

Absent oculovestibular reflexes

The oculovestibular reflex is tested by irrigating each ear with ice water (caloric testing) after the patency of the external auditory canal is confirmed. The head

is elevated to 30 degrees. Each external auditory canal is irrigated ( 1 ear at a time) with_10 to $50 \mathrm{~mL}$ of ice water. Movement of the eyes should be absent during 1 minute of observation. Both sides are tested, with an interval of several minutes.

3. Apnea. The patient must have the complete absence of documented respiratory effort (if feasible) by formal apnea testing demonstrating a $\mathrm{PaCO2}$

$>60 \mathrm{~mm} \mathrm{Hg}$ and $>20 \mathrm{~mm} \mathrm{Hg}$ increase above baseline.

- Normalization of the $\mathrm{pH}$ and $\mathrm{PaCO} 2$, measured by arterial blood gas analysis, maintenance of core temperature _ $35^{\circ} \mathrm{C}$, normalization of blood pressure appropriate for the age of the child, and correcting for factors that could affect respiratory effort are a prerequisite to testing.

- The patient should be preoxygenated using $100 \%$ oxygen for 5-10 minutes prior to initiating this test.

- Intermittent mandatory mechanical ventilation should be discontinued once the patient is well oxygenated and a normal PaCO2 has been achieved.

- The patient's heart rate, blood pressure, and oxygen saturation should be continuously monitored while observing for spontaneous respiratory effort throughout the entire procedure.

- Follow up blood gases should be obtained to monitor the rise in $\mathrm{PaCO} 2$ while the patient remains disconnected from mechanical ventilation.

- If no respiratory effort is observed from the initiation of the apnea test to the time the measured PaCO2_60 mm $\mathrm{Hg}$ and _ $20 \mathrm{~mm} \mathrm{Hg}$ above the baseline level, the apnea test is consistent with brain death.

- The patient should be placed back on mechanical ventilator support and medical management should continue until the second neurologic examination and apnea test confirming brain death is completed.

- If oxygen saturations fall below $85 \%$, hemodynamic instability limits completion of apnea testing, or a PaCO2 level of _ 60 mm $\mathrm{Hg}$ cannot be achieved, the

infant or child should be placed back on ventilator support with appropriate treatment to restore normal oxygen saturations, normocarbia, and

hemodynamic parameters. Another attempt to test for apnea may be performed at a later time or an ancillary study may be pursued to assist with

determination of brain death.

- Evidence of any respiratory effort is inconsistent with brain death and the apnea test should be terminated.

4. Flaccid tone and absence of spontaneous or induced movements, excluding spinal cord events such as reflex withdrawal or spinal myoclonus.

- The patient's extremities should be examined to evaluate tone by passive range of motion assuming that there are no limitations to performing such an examination (eg, previous trauma, etc) and the patient observed for any spontaneous or induced movements.

- If abnormal movements are present, clinical assessment to determine whether or not these are spinal cord reflexes should be done.

* Criteria adapted from 2010 American Academy of Neurology criteria for brain death determination in adults (Wijdicks et al, 2010).

Among all the other brain imaging modalities used to confirm brain death, a cerebral angiography that demonstrates complete interruption of $\mathrm{CBF}$ is considered the standard method by many authors, while a computed tomography angiography (CTA), magnetic resonance angiography (MRA) and perfusion studies have a high specificity and sensitivity in adult patients [5]. A Transcranial Doppler ultrasonography (TCD) also offers advantages as a fast and easily-accessible method, although it has a limited use due to the high rate of false negative results $[6,7]$.
A comparison of previous studies using EEG and CBF approaches involving infants older than one month reported similar outcomes with both methods, with neither emerging as superior to the other [8].

In this study, we evaluated 20 patients diagnosed with brain death in our clinics, where more than 50 pediatric transplantations are performed every year. Demographic data, clinical findings, EEG and imaging findings of our patients were evaluated retrospectively. 


\section{PATIENTS AND METHOD}

The present study included patients who suffered brain death during hospitalization in the pediatric intensive care unit of the Inonu University Turgut Ozal Medical Center between 2010 and 2017. In total, 20 patients with brain death were evaluated in this study, for which their medical files were reviewed retrospectively.

The criteria for a diagnosis of brain death include the status of coma, immobility, absence of spontaneous respiration and lack of oculocephalic, vestibulo-ocular, corneal, palatal and tracheal brainstem reflexes [9]. Detailed neurological examination oculocephalic, vestibulo-ocular, corneal, palatal and tracheal brainstem reflexes were evaluated.

All patients included in the study underwent an EEG lasting for 20-30 minutes. EEG's role in determining BD diagnosis is controversial since it cannot record brainstem function cessation. Patients with electro cerebral silence (ECS) on their EEG may have normal brainstem function and viceversa in BD patients with loss of brain function, cortical activity (even transitory) may be traced.

Imaging methods were carried out for some patients and an apnea test was performed on all patients, and was considered positive when the patient did not show any respiratory effort, despite $\mathrm{PaCO} 2$ levels of $\geq 60 \mathrm{mmHg}$ and increased for $\geq 20 \mathrm{mmHg}$ compared to the baseline value. CBF was measured by CTA, MRA and TCD, and the results were considered positive when an absence of flow was identified.

A diabetes insipidus (DI) diagnosis was made in the presence of pollakiuria for at least two consecutive hours (urine output $>4 \mathrm{~mL} / \mathrm{kg} / \mathrm{hour}$ in children weighing $\geq 70 \mathrm{~kg},>300$ $\mathrm{mL} /$ hour in children weighing $<70 \mathrm{~kg}$ ), hyponatremia (Serum Na> $145 \mathrm{mmol} / \mathrm{L}$ ), high serum osmolality (> 300 $\mathrm{mOsm} / \mathrm{kg}$ ) and low urine osmolality (<300 mOsm/kg).

Brain death information was given to the families of patients by the brain death committee, psychologist and psychiatrist.

Ethical board approval (2018/10-5 decision number) for the study was from the Inönü University Scientific Research and Publication Ethics Board. Financial support for the study was not received from any institution. Patients were not approved because it was a retrospective study.

\section{RESULTS}

The study included 20 patients with confirmed brain death, of which nine (45\%) were female and 11 (55\%) were male, corresponding to an M/F ratio of 1.22. The age range was $1-$
Table 2. Demographic information and examinations performed

\begin{tabular}{|c|c|}
\hline Patient & $n(\%)$ \\
\hline Age (Mean \pm SD) & $1-17(8,45 \pm 5,93)$ \\
\hline \multicolumn{2}{|l|}{ Gender } \\
\hline Male & $11(\% 55)$ \\
\hline Female & $9(\% 45)$ \\
\hline Auxiliary Tests & n (\%) \\
\hline EEG & $20(\% 100)$ \\
\hline CT angiography & $3(\% 15)$ \\
\hline MR angiography & $5(\% 25)$ \\
\hline Transkraniyal doppler & $3(\% 15)$ \\
\hline \multicolumn{2}{|l|}{ Diagnoses } \\
\hline Fulminan Hepatitis & $7(\% 35)$ \\
\hline Sepsis & $3(\% 15)$ \\
\hline Trauma & $3(\% 15)$ \\
\hline Drowning & $2(\% 10)$ \\
\hline CVD & $2(\% 10)$ \\
\hline Electric shock & $1(\% 5)$ \\
\hline Suicide & $1(\% 5)$ \\
\hline Lymphoma & $1(\% 5)$ \\
\hline Organ donors & $2(\% 10)$ \\
\hline DI diagnoses & $9(\% 45)$ \\
\hline After brain death (4-7 day) Na mean & $152,2 \pm 16,2 \mathrm{mmol} / \mathrm{L}$ \\
\hline Hospitalization (mean) & 4-40aün (167+107 aün) \\
\hline Hospitalization -Brain Death Diagnosis & $\begin{array}{l}\text { 4-40 gun }(16,1 \pm 10, / \text { gun }) \\
2-33 \text { gün }(11,1 \pm 8,94 \text { gün })\end{array}$ \\
\hline $\begin{array}{l}\text { (mean) } \\
\text { Life After Brain Death Diagnosis (mean) }\end{array}$ & $1-25$ gün $(5,6 \pm 6,05$ gün) \\
\hline
\end{tabular}

EEG: Electroencephalography CT: Computed Tomography MR: Magnetic Rezonans CVD: Cerebrovascular diseases Na: Sodium

17 years and the mean age was $8.47 \pm 5.73$ years (Table 1 ). In total, seven (35\%) patients were followed-up with a diagnosis of fulminant hepatitis, three (15\%) patients were with trauma, three (15\%) had sepsis, two (10\%) were monitored after drowning and two (10\%) were diagnosed with CVD. One of these two patients with CVD had cerebral bleeding when healthy, while other patient experienced cerebral bleeding while being monitored for multiple factor deficiency. One of the patients with sepsis was being followed-up with a diagnosis of glutaric aciduria, one patient was being monitored due to cerebral palsy and one patient was a healthy individual in the past. Among the remaining patients, one patient each was followed up with lymphoma, electric shock and suicide (Tables 2 and 3). The families of only two (10\%) of the 20 patients donated the organs of the deceased (Table 2). Of all the patients, four were Syrian and others Turkish, and all four of these were followed-up with a diagnosis of liver failure (Table $\mathbf{3}$ ).

The duration of hospital stay of the study sample was 4-40 days (mean: $16.7 \pm 10.7$ days). The time between the hospital admission and diagnosis of brain death ranged between $2-$ 33 days (mean: $11.1 \pm 8.94$ days). In patients with confirmed brain death, the time between brain death and declared death/becoming organ donor ranged between 1-25 days (mean: 5.6 \pm 6.05 days). 
Table 3. Clinical features of patients

\begin{tabular}{|c|c|c|c|c|c|c|c|c|c|c|c|c|c|}
\hline $\begin{array}{l}\text { Patients } \\
\text { No }\end{array}$ & Gender & Age & $\begin{array}{l}\text { Primary } \\
\text { Disease }\end{array}$ & \begin{tabular}{|c|}
$\begin{array}{c}\text { Duration of } \\
\text { Hospitilization } \\
\text { (Day) }\end{array}$ \\
\end{tabular} & $\begin{array}{c}\text { Hospitalization- } \\
\text { diagnosis }\end{array}$ & $\begin{array}{c}\text { Life After Brain } \\
\text { Death (Day) }\end{array}$ & DI & AT & $\begin{array}{c}\text { MR } \\
\text { Anjio }\end{array}$ & $\begin{array}{c}\text { BT } \\
\text { Anjio }\end{array}$ & TCD & EEG & $\begin{array}{c}\text { Transplante } \\
\text { organs }\end{array}$ \\
\hline 1 & $M$ & 17 & Electric Shock & 9 & 3 & 6 & - & + & - & - & - & + & - \\
\hline 2 & $\mathrm{~F}$ & 16 & $\mathrm{FH}$ & 7 & 6 & 1 & + & + & + & - & - & + & - \\
\hline 3 & $M$ & $9(\mathrm{~S})$ & $\mathrm{FH}$ & 15 & 14 & 1 & + & + & - & - & - & + & - \\
\hline 4 & $\mathrm{~F}$ & 17 & CVD & 6 & 5 & 1 & + & + & + & - & - & + & + \\
\hline 5 & $M$ & 2 & CP+sepsis & 20 & 17 & 3 & - & + & - & - & - & + & - \\
\hline 6 & $M$ & $1,5(\mathrm{~S})$ & $\mathrm{FH}$ & 35 & 33 & 2 & + & + & - & - & + & + & - \\
\hline 7 & $M$ & $12(\mathrm{~S})$ & $\mathrm{FH}$ & 35 & 10 & 25 & + & + & - & + & - & + & - \\
\hline 8 & $\mathrm{~F}$ & 5 & $\begin{array}{c}\text { Multiple factor } \\
\text { deficiency +CVD }\end{array}$ & 14 & 2 & 12 & - & + & - & + & - & + & - \\
\hline 9 & $F$ & 11 & $\mathrm{FH}$ & 20 & 8 & 12 & + & + & - & - & - & + & - \\
\hline 10 & $\mathrm{~F}$ & 3 & $\begin{array}{l}\text { Drowning in } \\
\text { water }\end{array}$ & 7 & 6 & 1 & - & + & + & - & - & + & + \\
\hline 11 & $M$ & 8 & Lymphoma & 15 & 14 & 1 & - & + & - & - & - & + & - \\
\hline 12 & $\mathrm{~F}$ & 17 & Suicide & 20 & 8 & 12 & + & + & - & - & - & + & - \\
\hline 13 & $M$ & 1 & Trauma & 5 & 4 & 1 & - & + & - & - & + & + & - \\
\hline 14 & $M$ & 2 & $\mathrm{FH}$ & 40 & 33 & 7 & + & + & - & - & - & + & - \\
\hline 15 & $\mathrm{~F}$ & 1 & Drowning & 30 & 20 & 10 & + & + & - & - & + & + & \\
\hline 16 & $M$ & $9(\mathrm{~S})$ & $\mathrm{FH}$ & 4 & 2 & 2 & - & + & - & - & - & + & - \\
\hline 17 & $M$ & 16 & Sepsis & 15 & 10 & 5 & + & + & + & - & - & + & - \\
\hline 18 & $\mathrm{~F}$ & 3 & $\begin{array}{c}\text { Glutaric } \\
\text { asiduria+Sepsis }\end{array}$ & 8 & 5 & 3 & + & + & + & - & - & + & - \\
\hline 19 & $M$ & 10 & Trauma & 16 & 12 & 4 & + & + & - & + & - & + & - \\
\hline 20 & $\mathrm{~F}$ & 8,5 & Trauma & 13 & 10 & 3 & & & & & & & \\
\hline
\end{tabular}

EEG: Electroencephalography CT: Computed Tomography MR: Magnetic Rezonans CVD: Cerebrovascular diseases TCD: Transkranial Doppler FH: Fulminant Hepatititis AT: Apnea Tests S: Syrian

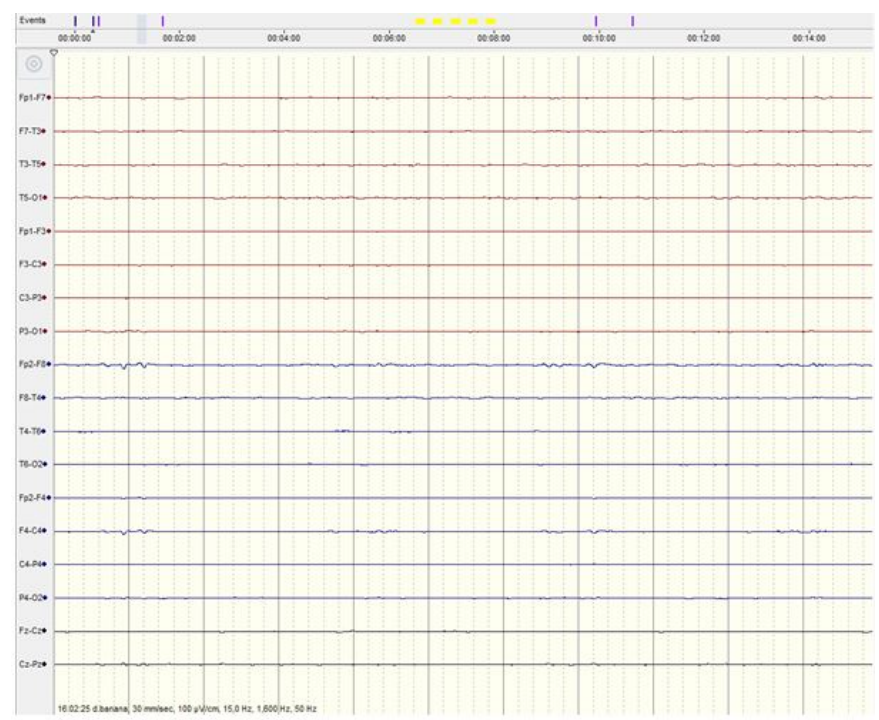

Figure 1. ECS on EEG of the patient who experienced an extravehicular traffic accident

In terms of the fundamental clinical examination findings, all patients had findings of coma and lost brainstem reflex, with glasgow coma scores (GCS) of 3. The patients had normal metabolic values and body temperatures (vital signs, electrolyte values) before the declaration of brain death, and an apnea test of all patients was positive. In all patients, EEG findings supported brain death diagnosis. In the EEGs, a diffuse voltage suppression, isoelectric line and ECS were present. Figure 1 shows the EEG imaging of a patient with confirmed brain death after an extravehicular traffic accident. In total, 12 (60\%) patients underwent the caloric test, resulting in positive results, while a CTA was performed on three patients (15\%), with CBF noted in only one of them. Figure 2 shows the absence of CBF in the CTA of a patient whose brain death occurred after drowning. An MRA was performed on five patients (25\%) and CBF was not observed in three of them. Figure 3 shows the absence of CBF in the MRA of a patient whose brain death occurred after CVD. 


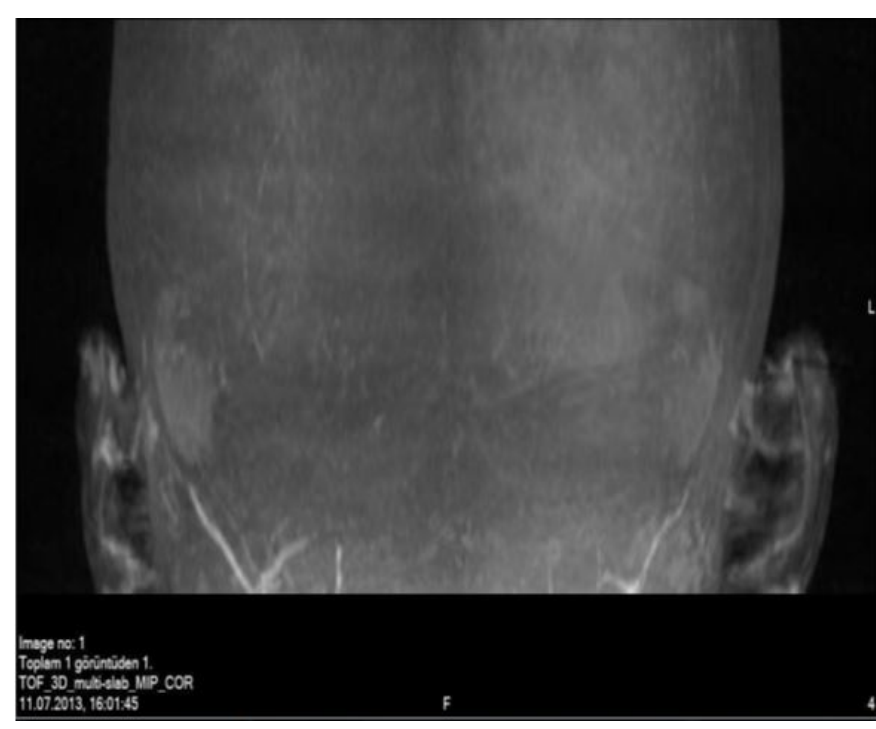

Figure 2. CTA of the patient whose brain death occurred after drowning

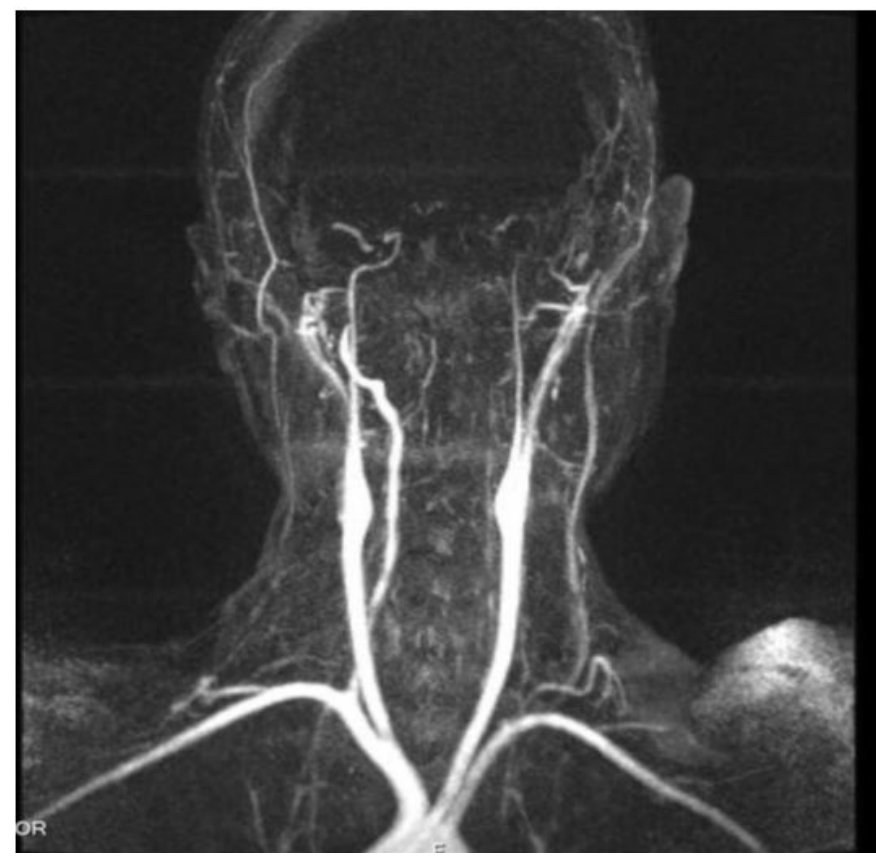

Figure 3. MRA of the patient whose brain death occurred after CVD

Furthermore, three patients underwent TCD and no flow was recorded in any of them (Tables $\mathbf{1}$ and $\mathbf{2}$ ).

Patients with confirmed brain death had normal biochemical parameter levels at the time of diagnosis. On the other hand, upon the progression of cerebral dysfunction, hypernatremia developed in 13 patients (65\%) during the follow-up period. Diabetes insipidus (DI) developed in nine (45\%) patients with brain death, and the mean $\mathrm{Na}$ levels of the patients who developed DI was found to be $152.2 \pm 16.2 \mathrm{mmol} / \mathrm{L}$ four to seven days after the diagnosis of brain death (Table $\mathbf{1}$ ).

\section{DISCUSSION}

The criteria for a diagnosis of brain death include the status of coma, immobility, absence of spontaneous respiration and lack of oculocephalic, vestibulo-ocular, corneal, palatal and tracheal brainstem reflexes [9]. Prior to examination, such potential causes as intoxication, hypothermia and the use of sedative analgesics or neuromuscular blocker agents should be excluded [10]. Conditions that mimic brain death, such as cervical cord injuries, fulminant Guillain-Barre Syndrome, organophosphate intoxication, and baclofen and lidocaine toxicity should be also kept in mind. Based on patient's age, clinical evaluations should be performed twice within a time interval of 12-24 hours [9, 10]. In total, 20 patients with brain death were evaluated in this study, and clinical evaluations were repeated twice with a time interval of 24 hours during which the patients showed no brainstem reflexes. The patients had normal metabolic values and body temperatures before the declaration of brain death. Moreover, all patients had undergone an apnea test and had recorded positive results.

In literature, the $M / F$ ratio was found to be comparable in patients with confirmed brain death and age range was between 1-17 years $[8,11]$. In two different studies, the mean age was 7 and 7.8 years $[12,13]$, while in the present study, the age range was 1-17 years and the mean age was $8.47 \pm 5.73$ years. Of the 20 patients, four were Syrian, all four of which were followed-up with liver failure. There is a lack of previous data on this issue, as this is the first study to be performed in Turkey since the arrival of Syrian refugees. The fact that more than half of the fulminant hepatitis patients with brain death were Syrian is an interesting finding that requires further investigation.

It should be multidisciplinary for brain death. We are working together with anethesis, neurosurgery, pediatric cardiology, while deciding on brain death. In several studies, trauma has been reported as the most common cause of brain death, and the rates are similar in Turkey [1]. In a study by Gençpınar et al. [11], the rate of trauma-related brain death was reported as 47 percent, while Gündüz et al. [14] reported trauma-related brain death in 55 percent of the patients included in their study. In the present study, trauma-related brain death occurred in 15 percent $(n=3)$ of the patients, with the most common cause of brain death being fulminant hepatitis, observed in 35 percent $(n=7)$ of the patients. This can be attributed to the fact that our hospital is a transplantation center, and a high number of patients refer to our hospital with fulminant hepatitis. 
The duration of hospital stay is generally long in patients with confirmed brain death. In the present study, the mean duration of hospital stay was found to be $4-40$ days (mean: 16.7 \pm 10.7 days), while Gündüz et al. [14] reported a duration of hospital stay of between 3-40 days and a mean duration was 12.4 days. In several studies, diagnoses of brain death are made within two hours of admission to the hospital [15], while in two other studies, diagnoses of brain death were made 4.2 days and 6 days after hospital admission $[14,16]$.

DI is an expected outcome in patients with brain death [17], and various studies have reported DI rates varying between $35-75$ percent $[11,14]$. Similarly, the rate of DI was found to be 45 percent in the present study. The most important positive outcome of confirmed brain death is organ donation. In our study, only two (10\%) families gave consent for organ donation, while in a study by Gündüz et al. [14] that was carried out in Turkey, the rate of organ donation was found to be 25 percent. This rate is reported as being much higher in several studies performed in other countries, for instance, this rate is almost 70 percent in Japan [18].

The fundamental triad for the diagnosis of brain death includes coma, the absence of brainstem reflexes and an unsuccessful apnea test, although most clinicians insist on supportive tests such as EEG, imaging methods measuring $\mathrm{CBF}$, and caloric tests to confirm brain death [2,3]. EEG in particular is in common use among pediatric neurologists. In the present study, EEG imaging was performed for all patients, and ECS was noted in all of them. Similarly, in the study by Gündüz et al. [14], EEG was performed in 90 percent of the patients and the results were comparable to our findings.

Another supportive test involves the use of imaging methods to measure CBF. Characteristic findings in MRA include transtentorial and foramen magnum herniation, the absence of intracranial contrasting and widening of the carotid artery. In recent years, TCD has become more common as a non-invasive and widely available approach, although current studies suggest that this technique has limited use in the confirmation of brain death due to the high rate of false negative test results as well as low levels of specificity and sensitivity [5- 7]. In the present study, 11 patients underwent imaging (three patients underwent CTA, five patients underwent MRA and three patients underwent $T C D$ ) and $(B F$ was not observed in any patients.

In conclusion, additional tests are required for a diagnosis of brain death, among which, EEG is particularly important as a non-invasive and easily-applicable procedure. The development of hypernatremia in patients with $\mathrm{DI}$ is now an important parameter in the loss of brain function.

\section{DECLARATION OF CONFLICT OF INTEREST}

The authors received no financial support for the research and/or authorship of this article. There is no conflict of interest.

\section{REFERENCES}

1. American Academy of Pediatrics, Task Force on Brain Death in Children. Report of Special Task Force: guidelines for determination of brain death in children. Pediatrics. 1987; 80: 298 -300.

2. Nakagawa TA, Ashwal S, Mathur M, Mysore M. Society of Critical Care Medicine, Section on Critical Care and Section on Neurology of American Academy of Pediatrics; Child Neurology Society. Clinical reportGuidelines for the determination of brain death in infants and children: an update of the 1987 task force recommendations. Pediatrics. 2011; 128: 720-40.

3. Nakagawa TA, Ashwal S, Mathur M, Mysore MR, Bruce D, Conway EE Jr, et al. Society of Critical Care Medicine; Section on Critical Care and Section on Neurology of the American Academy of Pediatrics; Child Neurology Society. Guidelines for the determination of brain death in infants and children: an update of the 1987 Task Force recommendations. Crit Care Med. 2011; 39: 2139-55.

4. American Electroencephalographic Society. Guideline three: minimum technical standards for EEG recording in suspected cerebraldeath. J Clin Neurophysiol. 1994; 11: 10-3.

5. Coker SB, Dillehay GL. Radionuclide cerebral imaging for confirmation of brain death in children: the significance of dural sinus activity. Pediatr Neurol. 1986; 2: 43-46.

6. Ashwal S, Smith AJ, Torres F, Loken M, Chou SN. Radionuclide bolus angiography: a technique for verification of brain death in infants and children. J Pediatr. 1977; 91: 722-7.

7. Garrett MP, Williamson RW, Bohl MA, Bird CR, Theodore $\mathrm{N}$. Computed tomography angiography as a confirmatory test for the diagnosis of brain death. J Neurosurg. 2017; 17: 1-6.

8. Drake M, Bernard A, Hessel E. Brain Death. Surg Clin North Am. 2017; 97: 1255-73. 
9. Kainuma M, Miyake T, Kanno T. Extremely prolonged vecuronium clearance in a brain death case. Anesthesiology 2001; 95(4): 1023-4.

10. Ostermann ME, Young B, Sibbald WJ, Nicolle MW. Coma mimicking brain death following baclofen overdose. Intensive Care Med 2000; 26(8): 1144-6.

11. Gençpınar P, Dursun O, Tekgüç $H$, Ünal A, Haspolat Ş, Duman Ö. Pediatric Brain Death: Experience of a Single Center Turkiye Klinikleri J Med Sci. 2015; 35(2): 60-6.

12. Au AK, Carcillo JA, Clark RS, Bell MJ. Brain injuries and neurological system failure are the most common proximate causes of death in children admitted to a pediatric intensive care unit. Pediatr Crit Care Med 2011; 12: 566-571.
13. Joffe AR, Shemie SD, Farrell C, Hutchison J, McCarthyTamblyn L. Brain death in Canadian PICUs: demographics, timing, and irreversibility. Pediatr Crit Care Med 2013; 14: 1-9.

14. Gündüz C, Şahin Ş, Uysal-Yazıcı M, et al. Brain death and organ donation of children. The Turkish Journal of Pediatrics 2014; 56: 597-603.

15. Ashwal S, Serna-Fonseca T. Brain death in infants and children. Crit Care Nurse 2006; 26: 117-124, 126-128.

16. Tsai WH, Lee WT, Hung KL. Determination of brain death in children-a medical center experience. Acta Paediatr Taiwan 2005; 46: 132-137.

17. Alharfi IM, Stewart TC, Foster J, Morrison GC, Fraser DD. Central diabetes insipidus in pediatric severe traumatic brain injury. Pediatr Crit Care Med 2013; 14(2): 203-9.

18. Shemie SD, Pollack MM, Morioka M, Bonner S. Diagnosis of brain death in children. Lancet Neurol 2007; 6: 87-92. 